\title{
CORRELATION OF PARENT RELATIONSHIP AND RELIGIOUS GUIDANCE IN SCHOOL WITH LEADERSHIP STUDENTS IN MADRASAH TSANAWIYAH NEGERI (MTsN) DEPOK
}

\author{
Haris Fadillah $^{\text {a) }}$, Muhyani ${ }^{\text {a) }}$, Kholil Nawawi ${ }^{\text {a) }}$ \\ a)Universitas Ibn Khaldun, Bogor, Indonesia \\ Corresponding Author: harkaharka95@gmail.com
}

Article history: received 02 January 2019; revised 15 January 2019; accepted 21 February 2019

\begin{abstract}
Parenting is an illustration of the attitudes and behavior of parents and children in interacting, communicating during holding parenting activities. In the activity of providing this care, parents will give attention, regulations, discipline, gifts and punishments, as well as responses to the wishes of their children. Parents' attitudes, behaviors, and habits are always seen, assessed, and imitated by their children who then will consciously or unconsciously be impregnated then become a habit for their children.Parents or mothers and fathers play an important role and greatly influence the education of their children. since a child was born, it was his mother who was always beside him. Therefore he imitates his mother's temperament and usually, a child is more in love with his mother, if the mother does her job well. This study aims to determine the relationship of parenting students with leadership in MTsN Depok, knowing the relationship of religious guidance of students with leadership in MTsN Depok, and to find out how much the relationship between parenting and religious guidance with the child's leadership in MTsN Depok. The type of research used in this study is quantitative research. The researcher used triangulation or combined data collection techniques, namely different data collection techniques to obtain data from the same source. Analysis of the data used is validity and product moment test. After calculating with Pearson correlation obtained rxy gain of 0.47 . At the index $0.40-0.70$, which means there is a moderate or sufficient correlation between variables $\mathrm{X}$ and $\mathrm{Y}$. It turns out the results of "product $\mathrm{r}$ " moment, the calculated $\mathrm{F}$ value is 0.475 with $\mathrm{F}$ table 0.195 . Once calculated, the amount of Fcount> Ftable or $0.475>0.195$, then the null Hypothesis (Ho) is rejected, and means the alternative Hypothesis (Ha) is accepted. And it can be concluded that there is a significant relationship between parenting $\left(\mathrm{X}_{1}\right)$ and religious guidance $\left(\mathrm{X}_{2}\right)$ with the leadership of children $(\mathrm{Y})$ in MTsN Depok.
\end{abstract}

Keywords: Parenting Parenting, Religious Guidance, Soul of Leadership

\section{INTRODUCTION}

As is known, the Indonesian nation recently showed a very severe symptom of moral decline, ranging from drug cases, corruption cases, legal injustice, promiscuity among teenagers, students and even students, the rise of violence, riots, anarchist acts and so on, indicating a shift to the direction of uncertainty of identity and national character. Of all the events that occurred, moral degeneration in adolescents was the most highlighted, because adolescents were the future successors of the nation.

The reason teenagers make mistakes is also due to lack of trust and confidence in themselves and their abilities. They cannot lead themselves to good things. A bad environment will easily bring anyone who lacks confidence. Adolescence is also a period of instability in development. Not infrequently many teenagers experience feelings of insecurity in socializing. They prefer to spend themselves in front of a television or gadget.

This can happen not because of the child's mischief, the factor of educators and educational institutions also plays a role in this deviation. Many parents feel unable to educate their children, so the development of children is truly the responsibility of educational institutions that are trusted. The task of the parents seems to only provide physical needs without wanting to know about their child's psychological and psychological state. Many also from parents who are only concerned with children's academic affairs and do not care about their religious development and affairs.

Not far from what parents do, in school children only get teaching whose objects are only cognitive aspects. Not infrequently students who have low-value learning achievements are discriminatory. Achievements are mostly seen from the academic side. The effort of character building is again a personal task of students, which they should still be guided and directed.

In fact, the academic achievements of students do not necessarily determine the morality and morals of students, such as the case that occurred in Depok last December, the figure of RA, a 14-year-old teenager who was a culprit in AN during a brawl at Serong Bridge, Depok, West Java known as children who excel in Depok Public Middle 9. The school did not expect the RA to be involved in the hacking of 2nd grade MTs Arahmania students [1]. The Principal of Depok 9th Middle School, Eti Kuswandarini, said that the RA who was in the 9th grade was a smart and accomplished child at the school. Therefore, the school did not expect RA to 
do a stabbing during a brawl. This is only one form of the rampant moral deterioration that is happening now.

Education occupies a central position in development problems because the goal is to improve the quality of human resources. Therefore education is also a middle flow of development from all development sectors. But the wrong perception about development, which considers that development is merely material development can have an impact on the development of the education system, even though the success or failure of physical development depends on success in spiritual or spiritual development, which is unanimously interpreted as the psychological development of humans also is the main task of education [2].

Parents have an obligation to educate children to have good behavior by applying religious teachings as the main pillar that is a filter of the influence of the development of science and technology that can affect the growth of child psychology and it must be done as early as possible in children [3]. Indeed characters are not revealed, but are continually nurtured through thoughts and actions. Character is interpreted as a way of thinking and behaving that is unique to each individual to live and work together, both within the scope of family, society, nation and state [4]. which both are provisions for students and have an impact on the leadership spirit of students

Even though this matter about adolescent leadership has been conveyed by Rasulullah that is very different from the current reality. It was reported that the conquering leader was the best leader, and his army was the best of the army ", said the Prophet Muhammad SAW (HR. Ahmad bin Hanbal) in front of his companions fourteen centuries ago. Eight centuries after the Prophet Muhammad SAW died, what was reported was truly happening. The fortress of Constantinople, which is famous for being strong and tough, was finally subdued in the hands of the Muslims. The ulama ', including Syaikhul Islam Ibn Taymiyah, had time to present: "Among the dalaa'il nubuwwah, or prophetic signs of Muhammad SAW, is the word of the apostle which tells of the events that will occur in the future." Praise the Prophet to the leader and the army which later succeeded in conquering Constantinople, really has whipped up the spirit of jihad of leaders and mujahideen who lived after him.

Finally Allah realized the dreams of the Muslims to conquer the fort through the hands of the 7th leader of the Uthmaniyyah Daula who was known for his piety and devotion to Allah. It is said that his army has never left the obligatory prayer since baligh and half of them have never left tahajjud prayers since baligh.

The success and greatness of Sultan Al-Fatih cannot be separated because of bimbigan and the great way of educating his parents. Following in the footsteps of the parents of Al-Fatih, parents at home should be able to make themselves a guideline that can be trusted by the child because when children start believing it, educators easily instill good things from the child. Education will facilitate their future life with the knowledge they have and the characters that have been formed and the skills that have been trained before when they learn to advance the lives of children in harmony with nature and society.

The importance of the example is also discussed in Al-Quran Al-Ahzab verse: 21

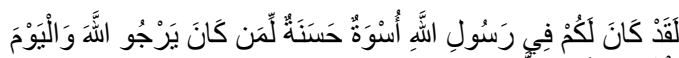

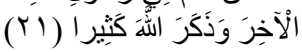

Surely there is in (the) Rasulullah a good example for you (that is) for those who wish (the mercy) of Allah and (the coming of) the Day of Judgment and he mentions Allah a lot.

Building the character and mentality of a good child is done as early as possible, if at a time when a bad environment influences it, the child has been provided with a permanently positive character. Building a child's character also means paying attention to the child at all times. As age goes on, children will always learn and always find new things, in every decision, a child who has been accustomed to doing something right to eat he will make the standard of truth given by his parents a benchmark of truth in his life in making decisions.

Based on the description above, this study aims to determine the relationship between parents' parenting style and leadership in MTsN Depok, knowing the relationship of religious guidance of students with leadership in MTsN Depok, and to find out how much the relationship between parenting and religious guidance with Child leadership in MTsN Depok.

\section{RESEARCH METHODS}

The research method used is a quantitative method. The place and time of this research was conducted at the Depok State in Madrasah Tsanawiyah Negeri (MTsN) which is located at Jl. Kp. Sawah No 31, Jatimulya, Cilodong, Depok City, West Java. While the time of the study the authors planned began on October 3 - October 29 2018. The population in this study were students of class VII to class IX in MTsN Depok with a population of 726 students and the number of samples set was 110 respondents. If the subjects studied are more than 100 can be taken $10 \%-15 \%$ or $20 \%-25 \%$, whereas if the number of students is less than 100 then all are taken because the number of students is more than 100 , the writer takes a sample of $15 \%$ from 726 , the researcher takes a sample of 110 students, namely 110 samples from 726 students.

This sample withdrawal the author uses random sampling technique, this technique is also called random, haphazard, indiscriminate / not favoritism, objective, so that all elements of the population have the opportunity to become a research sample. Data 
collection techniques used were questionnaires, and documentation studies. This questionnaire is given to students to obtain information from respondents to get reports about their personal or things they know, and documentation studies are used to find data on things or variables in the form of notes, transcripts, books, newspapers, magazines, inscriptions, minutes of meetings, briefs, agendas and so on. The method used to measure the respondent's answer is to use a Likert scale for parents' parenting variables, religious guidance in school and student leadership spirit.

\section{RESULTS AND DISCUSSION}

Leadership is a process of moving people in an organization because it has the power, authority and ability, so that working in a high moral atmosphere can enthusiastically complete their respective work according to the expected results.

According to Silalahi leadership is an activity that influences the behavior of others, both individually and in groups to carry out activities in an effort to achieve goals in certain situations. Leadership that is never consistent and unreliable, undoubtedly innovative ideas will continue to be hidden [5]. Al-qurans discuss many issues of life, one of which is leadership. In the Qur'an the leadership is expressed in various terms including caliph, imam, uli al-amr, and many others

The soul of leadership is not only the nature that comes by itself, or we are familiar with talent, but also influenced by factors that are around someone, such as family, society, people who are older even from the story of a book. , the factors of educators and educational institutions also play a role in character building. Many parents feel unable to educate their children, so the development of children is truly the responsibility of educational institutions.

As the first and foremost education unit, the family (parents) has a very important role in mental formation, father and mother figure are so dominant in the lives of children at home.

Parenting, according to Baumrind, is a consistent pattern of behavior and attitudes of parents in interacting and relating to their children based on two dimensions, namely demanding and responsive [6]. Parenting is a habit that is usually done by fathers and mothers that are applied to children in their development [7].

Parenting is an illustration of the attitudes and behavior of parents and children in interacting, communicating during holding parenting activities. In the activity of providing this care, parents will give attention, regulations, discipline, gifts and punishments, as well as responses to the wishes of their children. Parents' attitudes, behaviors, and habits are always seen, assessed, and imitated by their later children, consciously or unconsciously, they will be impregnated then become a habit for their children. This will affect the child's development.

There are several types of parenting, according to Dianna Baumrinde quoted by Rosyadi in his book Islamic Education in Forming the Character of Early Childhood, he divides parenting into three characters namely authoritarian, permissive, and authoritative parenting.

Regarding parenting, Abdullah Nashih Ulwan explained about the principles of effective education in children's education, the first is Education with exemplary, Abdullah Nashih Ulwan revealed that exemplary in education is the most convincing method of success in preparing and forming children in morals, spiritual, and social. This is because educators are the best example in the child's view, which he imitates is not his horn, and his manners, consciously or unconsciously, are even printed in the soul and feelings of the educator's picture, whether in speech or deed, whether material or spiritual, known known.

The second is education with customary customs. One of the provisions in Islamic teachings is that every human being is created by Allah with pure tauhid nature, straight religion, and faith in Allah. So that every child born carries potential, one of which is religious potential, namely the religion of monotheism. This religious potential can grow in children through 2 factors, namely: the main Islamic education factors and good environmental education factors. The factor of Islamic education that is fully responsible is the father of his mother. It is the character of the child. This is in accordance with the words of the Rasulullah SAW narrated by Muslims from Abu Hurairah.

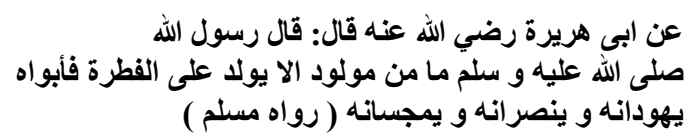

"From Abi Hurairah ra. has said the Rasulullah SAW. no child is born, except in a state of fitrah. Then it was his parents who would make him Jewish, Christian, or Magi. " (HR Muslim).

The third is education with advice, another important method in education, the formation of faith, preparing moral, spiritual and social children, is education by giving advice. Because the advice can open the eyes of the children to the essence of something, and push it towards a noble situation, and decorate it with noble character, and provide it with Islamic principles. So do not be surprised if in the Qur'an uses this method, which speaks to the soul, and repeats it in several verses and places [8].

A happy family is a very important thing for the emotional development of its members (especially children). Happiness is obtained if the family can play its function properly. The basic function of the family is 
to give a sense of belonging, security, affection; and develop good relationships between family members. The relationship of love in the family is not limited to feelings, but also involves maintenance, a sense of responsibility, attention, understanding, respect, and the desire to develop the child he loves. Families whose relationships between members are not harmonious, full of conflict, or gap communication, can develop mental health problems for children. Children who are raised from unjust families, the favoritism between one child and another will grow into a hostile family between family members [8].

Guidance is a translation of the term guidance in English. In accordance with the term, then guidance can be interpreted in general as an aid. But for the true understanding, not every form of assistance is guidance. For example, if a teacher whispers the answer to an exam at the time of the exam, so that the students graduate, of course this assistance is not a form of assistance required with guidance. Likewise, for example, a child who helps cross an old grandmother during a busy road such assistance is not assistance in the sense of guidance. The form of assistance in the sense of guidance requires certain conditions, certain forms, certain procedures, certain implementation in accordance with the basis, principles and objectives [9].

In the context of Islamic education a teacher must always be in interaction with students inviting students to devote while teaching the field of study that is their responsibility. The technical delivery of spiritual education by non-PAI teachers can be carried out very flexibly, can be carried out at the beginning of learning activities, in the midst of learning activities, or at the end of learning activities. A simple example, for example, is that at the beginning of the lesson there is a child who arrives late, then the teacher can discuss discipline with time, then ask if anyone has not prayed Fajr, if there is one, the teacher instructs the child who has not had Fajr prayer immediately. Then the teacher explains the importance of prayer for humans. This role is the contribution of a teacher in terms of fostering religious awareness and mental health to his students [8].

To find out the results in this study, the researcher presents in order the results of the study including a general description of the results of the study, hypothesis testing, and discussion that explains the relationship between parenting and religious guidance of students with student leadership. The general description of the results of the study presents the recapitulation of the answers to the student questionnaire about several things regarding parenting, religious guidance in the school and leadership spirit. And also the general description of the results of the study describes the relationship of parenting and religious guidance in schools with student leadership. To find out the results of the relationship between parenting and religious guidance with the leadership spirit of children in MTsN Depok, researchers used data obtained from the results of questionnaires, namely by distributing directly to all students in MTsN Depok, in order to produce relevant data.

Based on the results of distributing parenting questionnaires parents can be categorized as "Good". This can be seen from the percentage average, namely: alternative answers "disagree" with a score of 1 has an average percentage of $3.72 \%$. Alternative "less agree" answers with a score of 2 have an average percentage of $6.96 \%$. The alternative "can't determine" answer with a score of 3 has an average of $24.51 \%$. Alternative answers to "agree" with a score of 4 have an average of $35.84 \%$. And alternative answers "strongly agree" with a score of 5 have an average percentage of $28.60 \%$. So that it can be concluded that parenting parents in MTsN Depok "Good".

Furthermore, the results of distributing religious guidance questionnaires can be categorized as "Good". This can be seen from the percentage average, namely: alternative answers "disagree" with a score of 1 has an average percentage of $1.14 \%$. Alternative "disagree" answers with a score of 2 have an average percentage of $2.92 \%$. The alternative "can't determine" answer with a score of 3 has an average of $13.93 \%$. Alternative answers to "agree" with a score of 4 have an average of $21.25 \%$. And alternative answers "strongly agree" with a score of 5 have an average percentage of $16.47 \%$. So that it can be concluded that religious guidance in MTsN Depok "Good".

Then the results of distributing questionnaires to student leadership can be categorized as "Good". " This can be seen from the percentage average, namely: alternative answers "disagree" with a score of 1 has an average percentage of $3.44 \%$. Alternative "less agree" answers with a score of 2 have an average percentage of $6.70 \%$. The alternative "can't determine" answer with a score of 3 has an average of $29.16 \%$. Alternative answers "agree" with a score of 4 have an average of $39.25 \%$. And alternative answers "strongly agree" with a score of 5 have an average percentage of $29.78 \%$. So it can be concluded that the leadership spirit of students in MTsN Depok is "Good".

From the data from the study of 110 respondents, the calculation results were tested using Product Moment correlation analysis using the SPSS 20 aid tool

Table 1. Results of Product Moment Calculation X and Y Model Summary

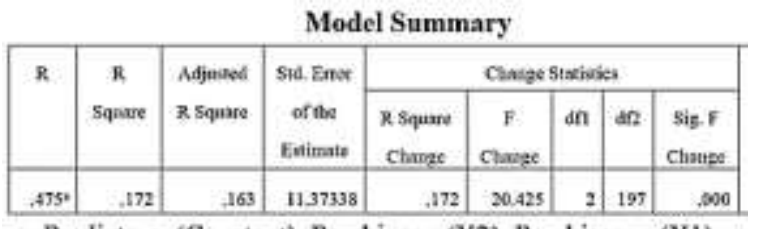

a. Predictors: (Constant), Pembinaan (X2), Pembiasaan (X1)

Based on the results of the above calculations obtained r_x $\mathrm{x}_{1} \mathrm{y}$ which is 0.475 or $0.47 \alpha=0.05$ which 
is located between $0.40-0.70$, it can be seen that there is a significant positive correlation between variables $X_{1}$, variables $\mathrm{X}_{2}$ and variables $\mathrm{Y}$ with moderate or sufficient correlation. Thus it can be concluded that there is a relationship between Parenting Parenting and Religious Guidance in Schools with Student Leadership Souls in Depok State Islamic Education. For the results of a more accurate interpretation of the value, the researcher tests the hypothesis that has been determined by comparing the magnitude of $\mathrm{r}_{-} \mathrm{x}_{1} \mathrm{x}_{2} \mathrm{y}$ with the large $\mathrm{r}_{-}$tabel by looking at the Value of the Correlation Coefficient Value Table, Product Moment from Correlation Pearson to share df.

In this study the number of respondents was 110 people, so to find $\mathrm{df}$ with the formula $\mathrm{df}=\mathrm{N}-2=110-2$ $=108$. Then the $\mathrm{r}$ table has a significance level of $5 \%$ 0.195 and $1 \%$ 0.254. By comparing $r_{-}$(arithmetic) and $r_{-}$ (table,) it turns out that $r_{-}$(count) is greater than $r_{-}$tabel both at a significant level of $5 \%$ or $1 \%$, so the null hypothesis (Ho) is rejected and the alternative hypothesis ( $\mathrm{Ha})$ is accepted.

Based on the explanation of the results of the above research, information can be obtained, that Parental Parenting and Religious Guidance in Schools with Student Leadership Souls in MTsN Depok have a correlation. This proves that there is a moderate or sufficient relationship between Parental Parenting and Religious Guidance in Schools with the Soul of Student Leadership. Where the results of the questionnaire that has been distributed to students and students of MTsN Depok class with the number of 110 respondents, after going through the calculation phase, it is obtained r_ $x_{1} x_{2} y$ of 0.47 .

\section{CONCLUSION}

Based on the results of the study concluded that, first there is a relationship between parenting parents of students with leadership in MTsN Depok. This can be proven from the results of the questionnaire distributed to 110 students who answered agreed at $35.84 \%$. Second, there is a relationship between the religious guidance of students and leadership in MTsN Depok. This can be proven from the results of the questionnaire distributed to 110 students who answered strongly agreeing at $21.25 \%$. Third, the relationship between parenting and religious guidance with the leadership spirit of children in MTsN Depok is at a moderate or sufficient level. This is evidenced from the results of the "r" product moment above, it turns out that the calculated $F$ value is 0.475 with $F$ table 0.195 . Once calculated, the amount of Fcount $>$ Ftable or 0.475> 0.195, then the null Hypothesis (Ho) is rejected, and means the alternative Hypothesis (Ha) is accepted. And it can be concluded that there is a significant relationship between parenting (X1) and religious guidance (X2) with the child's leadership spirit (Y).

Based on the results of the research, discussion, and conclusions described above, there are several suggestions that the researcher wants to put forward so that the personality of children or students can be better, especially in terms of leadership. First, this is shown to parents. Parents or guardians should pay more attention to parenting and better understand the interests of talent in children, so that children's development, especially in religion, can be better and so that a leadership spirit emerges in him. Second, this is shown to the teachers and educators, Should the daily life of the teacher always show a good example and improve communication to students so that they do good, especially in religious awareness. Third, to students to always be obedient and obedient to the rules at school and always try to find the identity that can be proud of in terms of kindness.

\section{REFERENCES}

[1] Rizky Adytia. 2017. Kriminologi.Id Pembacok Siswa MTs Depok Hingga Tewas Dikenal Berprestasi di Sekolah

[2] Umar Tirtahardja, Lasulo. Pengantar Pendidikan (Edisi Revisi) Jakarta : Asdi Mahasatya

[3] Nisak,H.K. 2012. No Title. Journal Of Nonformal Education and Community Empowerment, 1(1), 32-34.

[4] Dian. 2015. Pembentukan Karakter Melalui Pendidikan, dalam situs http://www.stp.dianmandala.org/2011/09/16/pembentukankarakter-melalui-pendidikan-oleh-dalifatiziliwu/ 10 April.

[5] Fajar Apriani. 2009 Pengaruh Kompetensi, Motivasi, dan Kepemimpinan terhadap Efektivitas Kerja, Bisnis \& Birokrasi, Jurnal Ilmu Administrasi dan Organisasi, vol 16 no 1

[6] Besse Intan Permatasari. 2015 Pengaruh Pola Asuh Oragtua, Gaya Belajar, Dan Motivasi Berprestasi Terhadap Prestasi Belajar Matematika Siswa MTsN Se-Makasar, MaPan : Jurnal Matematika dan Pembelajaran, Volume 3, Nomor 1, Juni

[7] S. Setiarani and Y. Suchyadi, 2018 "Pola Asuh Orang Tua Terhadap Anak Tuna Netra Berprestasi," J. Pendidik. Pengajaran Guru Sekol. Dasar, vol. 01, no. 01, pp. 15-18.

[8] Muhyani, 2019. Pengaruh Pengasuhan Orang Tua dan Peran Guru di Sekolah Menurut Persepsi Murid Terhadap Kesadaran Religius dan Kesehatan Mental. jakarta pusat

[9] Moh.Surya, Rochman Natawidjaja, Pengantar Bimbingan dan Penyuluhan. Universitas Terbuka, Jakarta 